\title{
Real estate interests versus conservation goals - The implantation of second-homes in the dunes of the Chilean coastal cordillera, Región de Valparaíso
}

\author{
Axel Borsdorf, Rodrigo Hidalgo Datwyler \& Sergio Elórtegui Francioli
}

Keywords: protected area, conservation, urbanization, real estate development, mountains, Chile

\section{Abstract}

Conflicts between protected area goals and those of other actors with land use plans are quite common. Normally the actors are farmers, concerned for their production methods, poor people searching for land or food, large industrial or hydropower businesses. The case is different for the dunes of Concón, located in the tongues of the Central-Chilean coastal cordillera. Large real estate companies are implementing their high-rise development projects near or even within protected areas for second-home owners. The consequences are significant: the territory of the dunes has been minimized, endangered species of flora and fauna have disappeared, the ecosystem itself is losing its functions. At the same time, the new inhabitants do not integrate into the community. They feel the loss of environmental quality that attracted them in the first place, but they feel no responsibility for that loss.

Profile

Protected area

Santuario de la Natura-

leza del Campo Dunar

de la Punta de Concón

Mountain range

Andes

Country

Chile

\section{Introduction}

Numerous conflicts exist between conservation and land use, in developing countries often arising from deprivation. Autochthonous population groups in particular find themselves restricted in their way of life and their survival strategy and breach the conservation regulations from dire need. Wehrhahn (1994), taking Brazil as his example, has raised the question of priority for conservation or protection of humans.

This tension takes on quite a different form in Chile, member of the OECD, with a steady rise in wealth in recent decades. Here it is the unrestrained activity of property developers, who plan and realize new projects within a neoliberal economic model, free from state restrictions and without regard for the protection of valuable ecosystems. The meta-cause of these activities is not need but the pursuit of profit and the desire of customers to live in pristine environments, a desire that self-destructs with its realization. This is not about the construction of main residences but predominantly about luxury second homes. We want to discuss this by looking at the dunes of Concón in the Chilean coastal cordillera, which, in the Metropolitan Region of Valparaíso / Viña del Mar, faces the double pressure of suburbanization and amenity migration from the capital Santiago (Borsdorf \& Hidalgo 2009). The promised amenities are the unique combination of mountains and sea (Borsdorf \& Hidalgo 2013) next to an expanse of higher dunes with a range of leisure options.
Theoretical framework

In Chile, which has pursued strictly neoliberal economic policies since 1974, the production dynamics of the property development sector have free reign in the market for land. The mechanisms of urban development and regional planning are largely inoperative. This observation follows the theoretical writings of Santos (2000) on the nature of space. For him the flows of capital via land speculation lead to irreversible changes of the initial space and to a restructuring of the situation within the regulatory space in terms of realpolitik. The new production of space is the result of an intimate interaction between the actors and the space formed by them. Silveira $(2011,15)$ concludes, "Whoever has the most power in society can determine the forms of land use."

The ideas of the French sociologist Henri Lefebvre have exerted a major influence on the theoretical contributions of Santos with respect to the idea of the production of space. The contributions made by Lefebvre during the 1970s are the basis for understanding the phenomenon of contemporary real estate production mode through their observations at the time. "While this aspect of the overall process (industrialization and / or urbanization) continues its evolution, the big city has exploded, causing a series of ambiguous developments, such as bumps: residential, industrial complexes, satellite towns, just different urbanized areas" (Lefebvre 1972, 10). Brenner (2013) called this a global urbanization.

The process of modern urbanization in the region of Valparaíso started with the construction of the Valparaíso-Santiago railway line in 1855 . The improved access sparked off the development of leisure resorts 
near Valparaíso and Viña del Mar (Cáceres \& Sabatini 2003). In the course of the $20^{\text {th }}$ century, this process reached Concón and led to the urban expansion of the Valparaíso region. A clear socio-spatial polarization emerged: The upper classes occupied lots with a sea view, the lower classes the quarters behind the shore line (Borsdorf \& Hidalgo 2008).

The 1980s and 1990s saw high-density construction in the first line and on the coastal terraces, with amenities such as sophisticated security infrastructure, transforming Reñaca and Concón into residential districts of the upper class (Negrete et al. 2000). These districts are characterized by socio-spatial segregation, gated vertical and horizontal communities, and gentrification in the traditional centres (Hidalgoe et al. 2014). The development of second homes attracted new economic activities to the area, but also created problems associated with segregation and the exclusion of the former residents of these communities.

The property developers apply a simple economic logic of profit maximization. They buy up attractive plots cheaply in areas that are not classified as building land in the spatial planning maps. Then they develop them with minimal investment and turn them into attractive and luxurious residences, which they sell immediately (Brenner et al. 2009). Such socio-economic interaction is found on all scales. The environment and its amenities on the one hand, and the desire for prestigious residences on the other, are the ingredients for spatial transformation, Santos (2009) calls this a dialectic relation.

However, the activities of the property developers do not remain uncontested. They face opposition from environmentalists on the one hand, and from political and civil society groups, on the other, especially groups from areas adjacent to the developed sites (Fuenzalida \& Quiroz 2012; Gudynas 2011; Volker 2012).

Given this situation, our study of the tensions between conservation and second-home development in the Chilean coastal cordillera covers several interesting aspects: The environmental potential of the steep slopes of the coastal cordillera (morphodynamics, biodiversity, effect on the local climate) is very valuable for their ecological balance and stability (Barragán 1997; Hidalgo et al. 2014). In addition there is the attractiveness of the landscape and its unique ecosystems and often endemic biocoenoses. In the past this has effectively prevented any property development. However, the withdrawal of the public administration from planning, the neoliberal economic model, growing wealth and the desire for high-end second homes are all endangering these unique ecosystems. We cannot offer any solutions given the current stable economic power structure. But we think it necessary to document the current dynamics in Chile to allow the timely introduction of controls in other regions where such developments have only just begun.

\section{State-of-the-art}

The establishment of the Chilean military regime and its subsequent political, economic and social ideology in late 1973 transformed the country to the neoliberal economic model and had significant consequences on urban structures as well as on society, education, economy, health, housing, labour and social welfare. The first phase, from 1973 to 1975, did not lead to a consensus among business associations (Montero 1997), while in the second phase, from 1975 to 1982, the existence of a technocratic body (socalled Chicago Boys), influenced by the liberal ideas of authors such as M. Friedman and F. von Hayek (Garate 2012), was characterized by the financialization of the economy and the commercialization of urban space, a state that continued into the 1990s and the early $21^{\text {st }}$ century. Investment in real estate began to be a profitable niche, as opposed to the manufacturing sector of the Chilean economy, which decreased in importance (Xavier \& Noble 2008; De Mattos 2008). This had significant territorial effects for the real estate boom in the central coastal area of Chile and the coastal cordillera.

The territorialization of the urbanization process has also generated new types of mobility, tensions, tourism and housing speculation around the coastal areas (Blazquez et al. 2011; Janoschka \& Haas 2014; Freeman \& Cheyne 2008).

In this sense the real estate production and consequent development of residential tourism have initiated a wave of privatizations in coastal areas. Such commodification of landscapes has been generated from the following explanatory axes: 1) the neoliberal policy, which has favoured the privatization of resources and services, and the transformation of nature into a commodity on the market; 2) power structures and formal and informal mechanisms to impose economic interests of business elites and subdue local actors by way of coercion and co-optation; 3) the weakness of the state, which provides ample scope for promoting and strengthening the private sector, to the detriment of local actors who did not have the legal and institutional mechanisms for conflict resolution at their disposal (Ávila \& Moon 2013 ).

In their search for new clients the real estate sectors discovered amenity migrants as possible buyers of primary or second homes. Kondo et al. (2012) address this concept from an economic perspective, referring to groups in search of a better quality of life provided by amenities like fresh air, healthy environment and local culture. In Latin America the desire for safe living behind fences or in high buildings is also important. Gonzalez (2011) regards this as a global phenomenon. From a more subjective perspective, Dewsbury \& Cloke (2009) mentioned the association of memories and emotions of the amenity migrants and the influence of touristic infrastructure (see also: Gonzalez 2011). This phenomenon has created a reversal of the traditional rural-urban mobility. Former tourists 
(re)visit places of leisure and may become permanent residents of the visited regions. In contrast to traditional migration concepts, amenity or lifestyle migration is based on personal wellbeing, not immediately aimed at economic interests (Morales \& Rainer 2013).

Janoschka (2013) stresses that in many Latin-American countries a new wave of migrants from the US, Canada and several European countries can be observed and calls this process lifestyle migration (see also: McIntyre 2009; Borsdorf 2009). It has an international scale and includes best-agers with high purchasing power, who move to countries with a low gross domestic product.

Cultural studies focused on gentrification refer to the theoretical perspectives of Bourdieu (1988), where social distinction plays an important role in the habitus, strategy and location of classes. Culture and social space acting as a device for social distinction where the amenities, places of consumption, services, nature, security, among others, are seen as real symbolic aspects that give identity to a dynamic middle class, constantly constituting and reconstituting themselves (Bourdieu 2001). Perlik (2011) directly addresses the lifestyle migration in the Alps as a process of gentrification.

Since initial works by Kohler $(1970,1971)$, the dunes of Concón have attracted the attention of a variety of researchers, although mostly from a geobotanical or geomorphological perspective. The unique genesis and morphodynamics of the dunes have been analysed by Araya (1997) and Paskoff et al. (2002). They emphasize the age of the dunes and their character as relicts of the Pleistocene. The flora of the dunes has been investigated by Serey et al. (1976), San Martin et al. (1992), Vidiella et al. (1999) and Luebert \& Muñoz (2005). The book by Gajardo (1994) on the natural vegetation of Chile included studies of the dunes of Concón.

Celis et al. (2012) extended the perspective to the complete ecological value of the study area. They investigated the biodiversity of the dunes and listed no fewer than 250 species. Their study allows including previously undetected species in this area.

From these studies we know about the floristic wealth of the dunes, but also about the stress factors influencing the unique biotope. Luebert \& Pliscoff (2005) also studied the bioclimatic situation of the Concón area and Luebert (2005) contributed an important chapter to the book, edited by Elórtegui (2005), who compiled a comprehensive view on the dunes and made recommendations for their conservation and for their sustainable future use.

To date the impact of the rapid urbanization has only been investigated by Cooper (2004). He included the neighbouring dunes of Ritoque in his study. Still missing is a study of the real estate development and urbanization of the area, which now affects even the protected area of the Santuario de la Naturaleza Dunas de Concón. Because of these activities, the delimitation of the sanctuary has been modified several

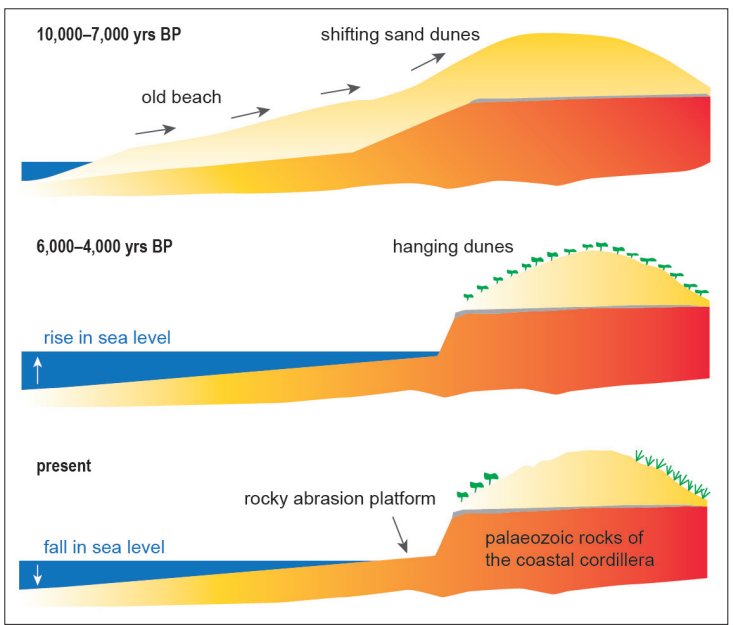

Figure 1 - Evolvement of the dunes of Concon (Source: Elortegui 2005, 18, modified by the authors).

times. It is the objective of this article to close this knowledge gap.

\section{Methods}

This study is based on botanical and spatial observation in the study area, realized over two decades by the authors, supported by remote sensing, semi-structured interviews with key players and citizens and a recent overflight with an aeroplane. In the cause of the analysis of the real estate sector a database has been generated from the extraction of census microdata from the years 1992, 2002 and 2012 using REDATAM software (retrieval of data for small areas by Microcomputer, realized by the Latin American and Caribbean Demographic Centre (CELADE), which is the Population Division of ECLAC, the Economic Division for Latin America and the Caribbean of the UN). The most important variable analysed was second-home ownership.

The 12 interviews were carried out by the authors with two real estate agents and ten residents of the new buildings. The texts have been transcribed and processed in the qualitative analysis program Atlas.ti vr.7. The analysis and interpretation was performed following the method of Mayring (2000).

\section{Study area}

The dunes of Concón are located at $32^{\circ} 56^{\prime} \mathrm{S}$ and $71^{\circ} 32^{\prime} \mathrm{E}$ on a rocky higher terrace of the Chilean coastal cordillera, around 80-100 m above sea level. They rise up to $100 \mathrm{~m}$ above the rocky terrace. This plain is made up of crystalline Palaeozoic rock and forms the lowest level of the coastal cordillera. The next level, about $3 \mathrm{~km}$ inland, is at $500 \mathrm{~m}$, rising to considerable elevations in the peaks of the Cerros La Campana (1829 m), Chache (2338 m) and Caqui (2192 m). Initially the Santuario de la Naturaleza covered an area of $45 \mathrm{ha}$, which was reduced in several instances to its current size of just 12 ha. Such a small 


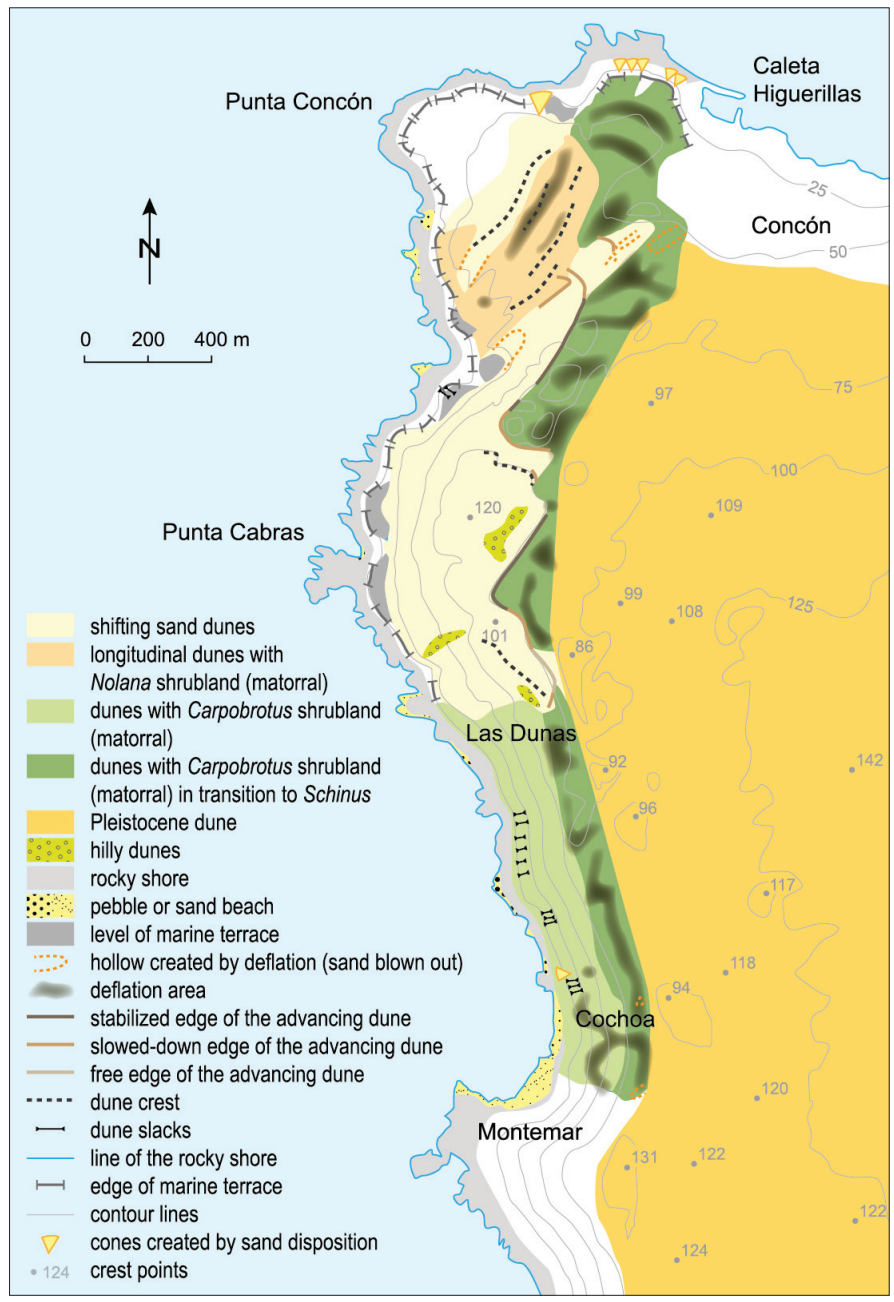

Figure 2 - Geomorphology of the dunes of Concon (Source: Elórtegui 2005, 17 , modified by the authors).

protected area cannot, of course, fulfil the criteria of a mountain (Borsdorf 2015), but it should still be understood as a protected mountain area because of the location of the Campo Dunar de Concón in an area that matches the description.

The Mediterranean climate (Cs) is affected by the cold Humboldt Current of the Pacific and includes frequent foggy periods in summer and rain in the winter months. The dunes started to develop about 10000 years ago in the early Holocene (Figure 1) in a warmer climate than today (Paskoff et al. 2002). The sand stems from the erosion of the coastal cordillera and was transported by the Marga-Marga and Reñaca rivers. The sea wind swept the sands over existing older dunes of Pleistocene origin, a very old landscape (Araya $1997,69)$. With the eustatic rise of the sea level from about $6000 \mathrm{BP}$, the supply of sand from the shore stopped and the dunes became isolated. Today we may call them hanging dunes, as they are no longer associated with a sandy beach alimenting them.

The dunes in the sanctuary area are still active, whereas in the east fossile dunes of Pleistocene age are no longer morphologically active and covered by forests (Figure 2). However, the area of active mor- phodynamics is nowadays very restricted because of the real estate developments of recent decades.

Biologists who carried out studies in the area agree that the principal characteristic of the ecosystems in the dunes of Concón is the enormous biodiversity (Kohler 1970, 1971; Serey et al. 1976; Gajardo 1994; San Martín et al. 1992; Cooper 2004; Luebert \& Muñoz 2005; Luebert 2005). The geological age of this Pleistocene-Holocene landscape, its location near the coast, affected by the cold Humboldt Current, with a particular microclimate with a cold uplift of water and air in summer, and the Mediterranean climate allow a combination of floristic elements and a higher variety of plants than on other dunes in Chile (Luebert 2005). For Luebert \& Pliscoff (2006) the flora of the Concón dunes is composed of an intrazonal community of Chorizanthe vaginata type B Ges. within the vegetation level of a sclerophyllous matorral, constituted by Peumus boldus and Schinus latifolius. Except for the Concón sanctuary, this rich ecosystem, which is present between Valparaíso and south of Coquimbo, is not protected in Chile.

Of the 186 species described by San Martín et al. (1992) in the dunes between Valparaíso and Puerto Montt, 159 are found in the dunes of Concón. 86\% of these plants are autochthonous (Luebert \& Muñoz 2005). They form four characteristic vegetation communities: (1) Babio ambrosioidis-Nolanetum crassulifoliae, (2) Margyricarpo-Chorizanthetum vaginatae, (3) Poa-Ambrosietum chamissoni and (4) Colletio bystricis-Schinetum polygamae, arranged in a specific profile (Figure 3).

The plant communities on the coastal slope and on the older dunes originate from the older Pleistocene dunes and today represent about $5 \%$ of their original area. Species existing in all four communities include Carpobrotus aequilaterus, Alstroemeria hookerii var. recumbens, Baccharis macraei, Margyricarpus pinnatus, Ephedra chilensis, Stachys grandidentata, Valeriana lobata, Puya chilensis, Ageratina glechonophylla, Lupinus microcarpus, Gamochaeta stachydifolia, Quinchamalium chilense and Glandularia porrigens. However, some plants seem to have been lost since 2010 because of external influences. These are Eriosyce curvispina, Tristagma bivalve, Haplopappus foliosus, Brachystele unilateralis and Chloraea berteroana. Urbanization and real estate activities already have created victims in biodiversity.

Associated with the vegetation, an extensive community of animals find their living space in the dunes, adapting their existence to the specific environment. 135 arthropods, 106 of them endemic (Celis 2012, 4) and 75 vertebrates, of which six are endemic in Chile (one amphibium, five reptiles, 62 birds, six mammals; Elórtegui 2005), find living conditions in the dunes. The insects are very important for the pollination of the plants (Lepidoptera, Hymenoptera). However, the fauna, too, is affected by urbanization. The amphibium Rhinella arunco or the reptile Liolaemus gravenhorstii have not been observed since 2013. This is also true of the birds Athene cunicularia, Nothoprocta perdicaria, Asthenes bumicola, Phrygilus alaudinus and Elanus leucurus. 


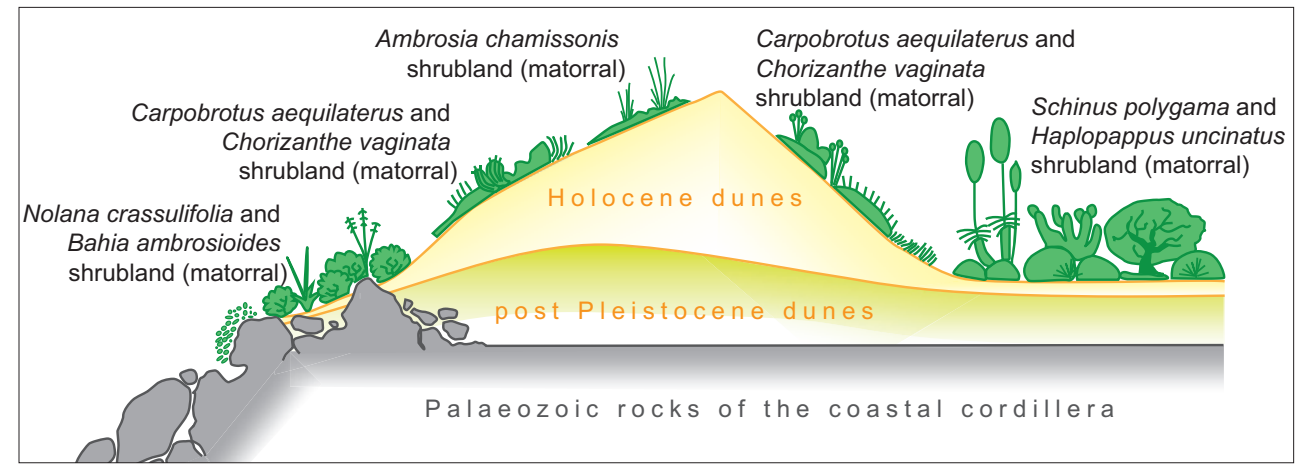

Figure 3 - Profile of the plant societies in the dunes of Concón (Source: Elórtegui 2005: 22, modified by the authors).

As found by Luebert \& Pliscoff (2006) the ecosystem of the dunes of Concón forms a community of species which is perfectly adapted to the environmental conditions. The phenology of the vegetation resembles more a flowering desert than the Mediterranean matorral (shrub). Villaseñor $(2005,112)$ described it as follows: "this vegetation appears floristically unique, without many relationships with the vegetation of the zone, and their species have more relationships with the semidesert of the III and IV region of Chile." Although some species are present in other ecosystems, too, the combination and the diverse interactions form the singular characteristics of this habitat and generate an original setting. It corresponds to phenological studies in the flowering deserts of Northern Chile (Vidiella 1999). In comparison with studies of the shrublands of the region of Valparaíso, the dune vegetation appears largely unrelated to the climatic vegetation of the region. It is a unique setting, which has not much varied within the last 15000 years (Paskoff et al. 2002).

\section{Results}

To protect the dunes of Concón, they were declared a Santuario de la Naturaleza on 5 August 1993. However, this national label is quite fuzzy (Praus et. al. 2011, 131) and does not meet the internationally controlled criteria of a biosphere reserve (Moreira \& Borsdorf 2014). Initially the protected area had a size of 45 ha. As early as 1994, however, and under pressure from developers, it was reduced to just 12 ha, to be expanded again to 19.5 ha in 2006 . The boundaries were again redrawn in 2012. Figure 4 shows the boundaries of the protected area for the years 1954, 1993 and 2014 the renewed modification of 2012 was left out for better readability). The designation of the protected area was carried out in view of the emerging urbanization of the dune area from the north (Figure 4).

Around 1995 development of the dune area took up speed, with the involvement of Euroinmobiliaria, ARDAC, Costa Brava, Costa de MONTEMAR, GEOMAR, Manantiales and RECONSA. Within the space of a few years, 34 blocks of flats were built on the southern side and 14 blocks of up to 34 floors on the northern side. Shopping centres sprang up on the western side, plus another 10 tower blocks. Table 1 lists the residential space created. We estimate that about $40 \%$ of these are second homes, with an upward trend. By 2012, declared second homes made up nearly half of the created residential space.

Table 1 - Creation of residential space in the Dunas de Concón 1995-2015 (Source: census and authors' calculations).

\begin{tabular}{|l|r|r|}
\hline Year & Built units & \% second homes \\
\hline 1997 & 7855 & No data \\
\hline 2000 & 3173 & 29.7 \\
\hline 2005 & 5457 & 34.3 \\
\hline 2010 & 4437 & 40.1 \\
\hline 2012 & 8984 & 48.5 \\
\hline
\end{tabular}

Asked what motivated the demand for second homes, a real estate agent answered, "It is about the qualities of the coastal landscape. This is a central point. The demand for apartments in tower blocks is fuelled by the closeness to nature, the sea view and the short distance to the beaches. In addition, these apartments are well served by trunk roads and excellent infrastructure nearby." $\mathrm{He}$ admits that there have been conflicts with the development plan in many cases and even demonstrations by the local population. "These have given rise to distrust of development projects. In view of the public protests the municipal authorities have started to apply the building regulations more strictly." Another agent lists the quiet situation, nature and the sea view. He said, "Today demand for second homes means searching for a residence that offers recreation and relaxation, not just in the holiday season but also at other times during the year." His comment on the planning authorities, "We are in constant contact with those who issue building permits. (...) If there is a particular regulation, we will find a solution to realize the project after all." These statements are evidence for the developers' orientation on demand and for their power.

All home owners we interviewed listed the location, the sea view, the proximity to the dune, the general quality of living and the closeness to the shopping centres as criteria for their purchasing decision. Some residents did show sensitivity to the environment, "Yes, there are conflicts, because the high-rise buildings impair the landscape." "There are great problems of access and little har- 


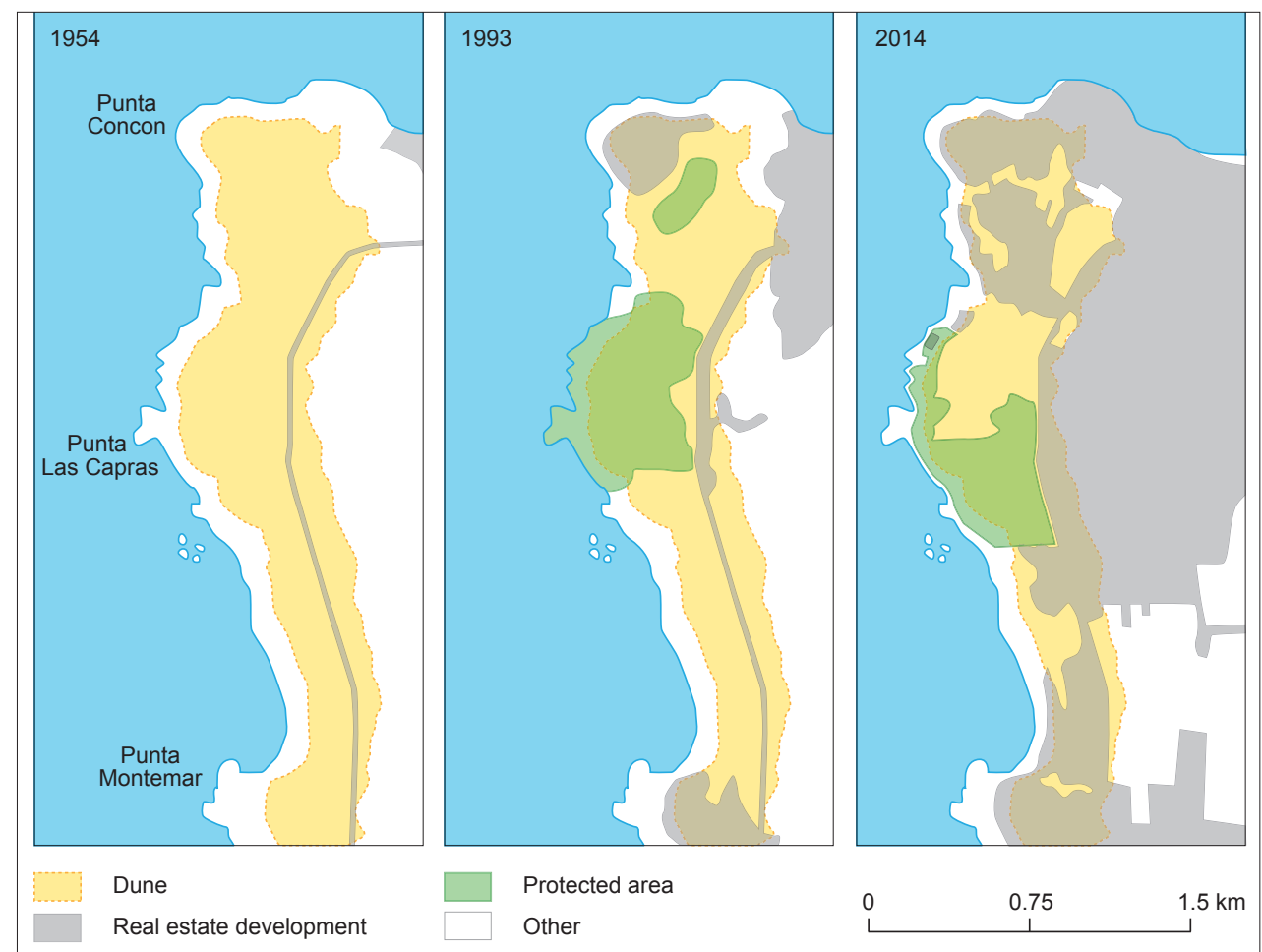

Figure 4 - Property development of the dunes of Concon (Source: Celis et al. 2012, 51, modified by the authors).

mony with the environment." "Yes, there are conflicts, because the environment, for instance the dunes, are being destroyed." Others play it down, "I do not see any big conflicts here." Or conflicts are noticed but not seen as problematic, "I think the view of the dunes suffers, but I don't mind."

\section{Discussion}

With growing wealth in the middle and upper classes in Chile, new forms of mobility have evolved with amenity and lifestyle migration (Borsdorf 2009; Borsdorf \& Hidalgo 2009). These include international forms (Hidalgo et al. 2014), however, in the municipality of Concón we find almost exclusively an influx of residents from the capital Santiago. Developers put large advertisements in Santiago's daily newspapers to attract this clientele. Mountains and the sea is a frequent argument (Borsdorf \& Hidalgo 2013).

The laissez-faire attitude of planning authorities in the age of neoliberalism in Chile has not stopped outside Concón. As a result, the economic power of the developers means that they can realize their projects without any real restrictions. In doing so they pay no attention to the environment or to the regulations protecting the ecologically invaluable dunes. The agents benefit from a growing class of wealthy people, especially in Santiago, who appreciate the amenities of a second home between the coastal cordillera and the Pacific, with free view of the sea, close to the beaches, good infrastructure and leisure options in the dunes. The new residents may notice the conflict with conservation and the growing protest of the locals, but they put their own interests over those of the environ- ment and the common good. And the protest is weak and still not formalized. No demonstrations or protest marches have been reported yet.

Imbalances between the protected area and increasing urbanization endanger the sustainability as huge residential and tourism projects are developed, which respect neither the environment nor the social coherence of the municipality. This concurs with the results of Jimenez \& Sosa (2010) in Mexico, specifically in Cancun and the Riviera Maya, where urbanization - like in Concón - has been realized without any planning and in their study area also without the implementation of infrastructure. As a result, the morphology, the natural heritage and systemic relationships between the components of the coastal ecosystem have been eliminated.

The real estate sector operates through various mechanisms, ranging from developments which transform the natural environment to the weak policy and land management instruments which neglect the protected area (Delgado 2008a). In the Metropolitan Area of Valparaíso (AMV), territorial planning instruments, specifically the Metropolitan Valparaíso Regulatory Plan (PREMVAL) has been developed and implemented without considering the participation of neighbourhoods or civil society organizations (Hidalgo et al. 2014).

The territorial consequences associated with this strategy are not only intensified construction of second homes but also fragmented urban enclaves close to the traditional city centre. Social relations between newcomers and traditional residents are underdeveloped (Huete \& Mantecon 2011; Huete \& Mantecon 
2013; Delgado 2008b). Similar issues have also been identified by Moss (2006, 2014). The socioeconomic transformations lead to an increase in the service sector, urban specialization, commodification (Perlik 2014) and have a severe impact on common (and also public) property (Rudzitis et al. 2014).

In Concón this has not only meant continuing development of the dune area from the fringes inwards, but also intensive use of the dunes for walking, picnics, sand surfing and other sports. These are pursued without regard for the numerous valuable biocoenoses. Plants are being pulled up, animals disturbed in their habitat and the dunes destabilized.

As early as 2005, Elórtegui developed a practicable alternative in the form of a town in harmony with the dunes and presented suggestions for preserving biodiversity in the dunes through targeted protection, strict urban planning and new plantings. His proposals fell on deaf ears. If the authorities do not act, and it is highly unlike that they will, then it will take just a few decades for a protected area with a unique ecology and diversity to have made way for the development of luxury apartments for wealthy Chileans.

The actors in the conflict in the coastal area are associated with the triad of public agents, private enterprises and civil society. Installation of real estate projects in areas of high ecological vulnerability poses a threat to resident communities and the environment. In this context territorial defence groups have emerged and even explore the options of due legal process to stem the real estate development

In this conflict, the real estate companies have the advantage of their greater economic power. They benefit from the lack of regulation by the local government (Hidalgo et al. 2014). However, it must be assumed that their activities may cause even more protest by civil society organizations (Hidalgo et al. 2016).

\section{Conclusion}

The dunes of Concón represent a unique ecosystem with a high degree of biodiversity, including many endemic species of flora and fauna. Therefore they were declared a protected area in 1993. Since then a dynamic urbanization process and real estate development has set in and numerous species have disappeared. Protection designations of endangered habitats often trigger conflicts with local land use. Such conflicts may arise out of dire need if they restrict the local population in their former land use and force them to adapt. In the case of the dunes of Concón, however, the pressure on the protected area does not stem from deprivation but from affluence. Second homes do not alleviate housing shortages, rather they are manifestations of an increasing desire for luxury. They remain empty for much of the year, yet claim acreage, resources and infrastructure. Only consistent regulatory policies can redress such abuse.

\section{Acknowledgements}

The authors wish to thank the Chilean research funding institution FONDECYT for financing the projects The transformation of central places: Commercial restructuring and residential gentrification. The case of Santiago, Valparaíso and Viña del Mar (support number 1095222) and Real estate and second homes: the city without limits in the towns of the coast in Valparaiso Region (1992-2012) (support number 1120223). We also thank CONICYT/ FONDAP for funding project number 15110020.

\section{References}

Araya, J.P. 1997. Fundamentación geomorfológica para la conservación y manejo de sistemas dunares. Revista Geográfica de Chile Terra Australis 42: 65-72. In Spanish]

Ávila, P. \& E. Luna 2013. Del ecologismo de los ricos al ecologismo de los pobres. Revista Mexicana de Sociología 75, 1: 63-89. [In Spanish]

Barragán, J. 1994. Ordenación, planificación y gestión del espacio litoral. Guía práctica para la planificación y gestión integradas. Barcelona, Oikos-Tau. [In Spanish]

Blázquez, M., E. Cañada \& I. Murray 2011. Búnker playa-sol. Conflictos derivados de la construcción de enclaves de capital transnacional turístico español en el Caribe y Centroamérica. Scripta Nova. Revista electrónica de Geografía y Ciencias Sociales XV (368). [In Spanish]

Borsdorf, A. 2009. Amenity Migration in mountain regions. Die Erde 139(3): 225-228.

Borsdorf, A. \& R. Hidalgo 2008. Open port closed residential quarters? Urban structural transformation in the Metropolitan Área of Valparaíso. Erdkunde 61: 1-13.

Borsdorf, A. \& R. Hidalgo 2009. Searching for fresh air, tranquility and rural culture in the mountains: A new lifestyle for Chileans? Die Erde 140(3): 275-292.

Borsdorf, A. \& R. Hidalgo 2013. Mountains and the sea: An analysis of the 2010 real estate and retail sectors in the Metropolitan Region of Valparaíso. Viña del Mar, Chile. Mountain Research and Development 33(3): 332-338.

Borsdorf 2015. Some difinitions of Mountains and High Mountains. In: Grover, V.I., A. Borsdorf, J.H. Breuste, P.C. Tiwari \& F.W. Frangetto (eds.), Impact of Global Changes on Mountains. Responses and Adaptation: 16-17.

Bourdieu, P. 1988. La distinción: criterios y bases sociales del gusto. Madrid. [In Spanish]

Bourdieu, P. 2001. Poder, derecho y clases sociales. Bilbao: Desclée de Brouwer. [In Spanish]

Brenner, N. 2013. Tesis sobre la urbanización planetaria. Nueva Sociedad: 38-66. [In Spanish]

Brenner, N., J. Peck \& N. Theodore 2009. Urbanismo neoliberal: la ciudad y el imperio de los mercados. Temas Sociales 66: 1-12. [In Spanish]

Cáceres, G. \& F. Sabatini 2003. Para entender la urbanización del litoral: balneario en la conformación del Gran Valparaíso (siglo XIX-XX). ARQ: 50-52. [In Spanish] 
Celis, J.L., F. Salinas \& J.J. Armesto 2012. Valor ecológico de Santuario de la Naturaleza Campo Dunar de la Punta Concón. Santiago. [In Spanish]

Cooper, F. 2004. Efecto del cambio de uso de la tierra sobre la vegetación y flora dunaria en la costa de Ritoque y Concón, Provincia de Valparaíso (V Región, Chile). Thesis, Universidad de Chile, Santiago. [In Spanish]

De Mattos, C. 2008. Globalización, negocios inmobiliarios y mercantilización del desarrollo urbano. In: Xavier, P. \& R. Hidalgo (eds.), Producción inmobiliaria y reestructuración metropolitana en América Latina. Santiago: GEOlibros: 23-40. [n Spanish]

Delgado, C. 2008a. Urbanización sin fronteras. El acoso urbanístico a los espacios naturales protegidos. Boletin de la Asociación de Geógrafos Españoles: 271-310. [In Spanish]

Delgado, C. 2008b. Vivienda secundaria y turismo residencial como agentes de urbanización y segregación territorial en Cantabria. Scripta Nova. Revista Electrónica de Geografía y Ciencias Sociales, XII, 269. [In Spanish]

Dewsbury, J.-D. \& P. Cloke 2009. Spiritual landscapes: existence, performance and immanence. Social \& Cultural Geography 10(6): 695-711.

Elórtegui Francioli, S (ed.) 2005. Las Dunas de Concón. El desafío de los espacios silvestres urbanos. Viña del Mar, Taller la Era. [In Spanish]

Freeman, C. \& C. Cheyne 2008. Coasts for Sale: gentrification in New Zealand. Planning Theory o Practice 9(1): 33-56.

Fuenzalida, M.Y. \& R. Quiroz 2012. La dimensión espacial de los conflictos ambientales en Chile. Polis 11(31): 157-168. [In Spanish]

Gajardo, R. 1994. La vegetación natural de Chile. Clasificación y distribución geográfica. Santiago, Editorial Universitaria. [n Spanish]

Gárate, M. 2012. La revolución capitalista de Chile (1973-2003). Santiago, Ediciones Universidad Alberto Hurtado. [In Spanish]

González, R. 2011. Los procesos de migracion de amenidad y la competitividad de destinos turisticos de montaña del oeste canadiense y de la norpatagonia argentina. Estudios y Perspectivas en Turismo 20: 1102-1122. [In Spanish]

Gudynas, E. 2011. Más allá del nuevo extractivismo: transiciones sostenibles y alternativas al desarrollo. In: Wanderley, F. (ed.), El desarrollo en cuestión. Reflexiones desde América Latina. La Paz, Oxfam \& CIDES UMSA: 379-410. [In Spanish]

Hidalgo, R., V. Alvarado, F. Arenas, A. Salazar \& P. Volker 2016. La comunidad disidente: reacción, método y conflictividad socio-espacial en el borde costero de la Región de Valparaíso. ACE: architecture, city and environment, in press. [In Spanish]

Hidalgo, R., A. Borsdorf \& G. San Martin 2014. Socio-spatial change in the world heritage site Valparaíso. Die Erde 144: 228-240.

Hidalgo, R., P. Volker \& N. Ramírez 2014. La ciudad inmobiliaria: mecanismos institucionales, relaciones de poder y mercantilización del medio natural. El caso del Área Metropolitana de Valparaíso. In: XIII Coloquio de Geocrítica, Barcelona May 5-10, 2014. Available at: http:/ /www.ub.edu/geocrit/ coloquio2014/Hidalgo \%20Volker\%20Ramirez.pdf (accessed 10/09/2014) [In Spanish]

Hidalgo, R., H. Zunino, O. Bender \& A. Borsdorf 2014. Metro-peripherical and lakeside amenity settlement: Chilean case studies. In: Moss, L.A.G. \& R.S. Glorioso (eds.), Global Amenity Migration. Transforming Rural Culture, Economy and Landscape. An examination of rural change and development in the Americas, Europe, Africa and Asia. Kaslo: 311-327.

Huete, R. \& A. Mantecón 2011. Más allá del turismo: movilidad residencial europea y nuevos núcleos urbanos. Boletín de la Asociación de Geógrafos Españoles 56: 111-128. [In Spanish]

Huete, R. \& A. Mantecón 2013. La migración de noreuropeos en España. Convergencia. Revista de Ciencias Sociales 20(61): 219-245. [In Spanish]

Janoschka, M. 2013. Nuevas geografias migratorios en América Latina: prácticas de ciudadanía en un destino de turismo residencial. Scripta Nova Revista Electronica de Geografía y Ciencias Sociales XVII, 439: 1-22. [In Spanish]

Janoschka, M. \& R. Durán 2014. Lifestyle migrants in Spain. Contested realities of political participation. In: Janoschka, M. \& H. Haas (eds.), Contested Spatialities, Lifestyle Migrations and Residential Tourism. New York: 60-73.

Janoschka, M. \& H. Haas 2014. Contested Spatialities, lifestyle migration and residential tourism. New York.

Jiménez, A. \& A. Sosa 2010. El turismo de segundas residencias en Cancún y la Riviera Maya: una visión panorámica de su evolución al inicio del milenio. In: Hiernaux, D. (ed.), Las segundas residencias en México: un balance. Mexico D.F., Plaza y Valdés: 37-95. [n Spanish]

Kohler. A. 1970. Geobotanische Untersuchungen an Küstendünen Chiles zwischen 27 und 42 Grad südlicher Breite. Botanisches Jabrbuch Syst. 90: 55-200. [In German]

Kohler. A. 1971. La vegetation des dunes maritimes du Chili. Colloques Phytosociologiques 1: 17-23. [In Spanish]

Kondo, M., R. Rivera \& S. Rullman 2012. Protecting the idyll but not the environment: second homes, amenity migration and rural exclusion in Washington State. Landscape and Urban Planning 106: 174-182.

Lefebvre, H. 1972. La revolución urbana. Madrid. In Spanish]

Luebert, F. 2005. Comunidades vegetales de las Dunas de Concón. In: Elórtegui, S. (ed.), Dunas de Concón: el desafío de los espacios silvestres urbanos. Viña del Mar, Taller La Era: 22-27. [In Spanish]

Luebert, F. \& M. Muñoz 2005. Contribución al conocimiento de la flora y vegetación de las dunas de Concón. Boletin del MNHN, Chile 54: 11-35. [In Spanish]

Luebert. F. \& P. Pliscoff 2006. Sinopsis bioclimática y vegetacional de Chile. Santiago de Chile, Ed. Universitaria. [In Spanish]

Mayring, P. 2000. Qualitative Inhaltsanalyse. Forum Qualitative Sozialforschung. Available at: http:// 
www.qualitative-research.net/fqs-texte/2-00/200mayring-d.pdf (assessed 20/03/2015).

McIntyre, N. 2009. Rethinking amenity migration: Integrating mobility, lifestyle and social-ecological systems. Die Erde 140(3): 229-250.

Montero, C. 1997. La revolución empresarial chilena. Santiago. [In Spanish]

Morales, S. \& G. Rainer 2013. Migración por amenidad y turismo: ¿dinámicas globales en el espacio rural? El caso de Tafí del Valle (Tucumán, Argentina). Pasos. Revista de Turismo y Patrimonio Cultural: 571-582. [In Spanish]

Moreira Muñoz, A. \& A. Borsdorf 2014. Reservas de la Biosfera de Chile. Laboratorios para la Sustentabilidad. Geolibros 17. Santiago de Chile, Pontificia Universidad Católica de Chile.

Moss, L.A.G. 2006. The Amenity Migrants. Seeking and Sustaining Mountains and their Cultures. Cabi.

Moss, L.A.G. 2014. The rural change agent amenity migration: some further explorations. In: Moss, L.A.G. \& R.S. Glorioso (eds.), Global amenity migration. Transforming rural culture economy and landscape. Kaslo: 11-30.

Paskoff, R., H. Manríquez, L. Cuitino \& R. Petiot 2002. Nuevos antecedentes sobre la geomorfología del campo de dunas colgadas de Concón (provincia de Valparaíso, V Región, Chile). Terra Australis 47: 43-50. [In Spanish]

Perlik, M. 2011. Alpine gentrification: The mountain village as a metropolitan neighbourhood. New inhabitants between landscape adulation and positional good. Journal of Alpine Research, Revue de Géographie Alpine 99(1). Available at: http://rga.revues.org/1370 (assessed 27/12/2015)

Perlik, M. 2014. The larger socio-economic dynamic of amenity-seeking practises. In: Moss, L.A.G. \& R.S. Glorioso (eds.), Global amenity migration. Transforming rural culture economy and landscape. Kaslo: 99-118.

Praus. S., M. Palma \& R. Dominguez (eds.) 2011. La situación jurídica de las actuales áreas protegidas de Chile. Creación de un sistema nacional integral de áreas protegidas para Chile. Santiago de Chile, PNUD. [In Spanish]

Rudzitis, G., P. Graves \& L.A.G. Moss 2014. Amenities, public goods and community. In: Moss, L.A.G. \& R.S. Glorioso (eds.), Global amenity migration. Transforming rural culture economy and landscape. Kaslo: 47-64.

Santos, M. 1996. Metamorfosis del espacio habitado. Series en textos de Geografía. Barcelona.

Santos, M. 2000. La naturaleza del espacio: Técnica y tiempo. Razón y emoción. Series en Geografía. Barcelona. [In Spanish]

Santos, M. 2004. Por otra globalización: del pensamiento único a la conciencia universal. Bogotá, Agenda Iberoamericana, Convenio Andrés Bello. [In Spanish]

San Martín, J., C. Ramírez \& C. San Martín 1992. La flora de las dunas chilenas y sus adaptaciones morfológicas. Bosque 13(1): 29-39. [In Spanish]

Serey, I., C. Sillard, N. Pizarro \& J. Rodríguez 1976. Diversidad de la vegetación de la dunas de Concon.
Anales Museo de Historia Natural de Valparaíso 9: 23-27. [In Spanish]

Silveira, M.L. 2011. Nuevo orden espacial de la globalización: encrucijadas y horizontes. Revista de Geografía Espacios 1: 1-17. [In Spanish]

Vidiella, P.E., J. Armesto \& J. Gutiérrez 1999. Vegetation changes and sequential flowering after rain in the Atacama Desert. Journal of Arid Environments 43: 449-458.

Villaseñor, R. 2005. Epílogo. In: Elórtegui Francioli, S. (ed.), Las Dunas de Concón. El desafio de los espacios silvestres urbanos. Viña del Mar, Taller la Era: 112. IIn Spanish]

Volker, P. 2012. Transformaciones socio-espaciales en Cerro Alegre y Cerro Barón, Valparaíso: el papel del sector inmobiliario y sus relaciones de poder. Thesis, Santiago de Chile. [In Spanish]

Wehrhahn, R. 1994. Konflikte zwischen Naturschutz. und Entwicklung im Bereich des Atlantischen Regenwaldes im Bundesstaat São Paulo, Brasilien. Untersuchungen zur Wahrnehmung von Umweltproblemen und zur Umsetzung von Schutzkonzepten. Kieler Geographische Schriften 89. Kiel. [In German]

Xavier, P. \& R. Hidalgo 2008. Producción inmobiliaria y reestructuración metropolitana en América Latina. Santiago de Chile: Serie GEOlibros Pontificia Universidad Católica de Chile / Facultad de Arquitectura y Urbanismo; Universidad de São Paulo. [In Spanish]

\section{Authors}

\section{Axel Borsdorf}

born 1948, is an emeritus of Geography at the University of Innsbruck and the director of the Institute for Interdisciplinary Mountain Research at the Austrian Academy of Sciences. Since 1971 he has continously done research in the mountain regions of Chile.

\section{Rodrigo Hidalgo Datwyler}

professor at the Pontificial Catholic University of Chile in Santiago, received his PhD in Barcelona, Spain. He is a renowned urban researcher and has been Chile's Geographer of the Year 2015. He is editor of the jorunal Norte Grande and has published several books on Chilean geography and urban systems. Instituto de Geografía, Pontificia Universidad Católica de Chile, Campus San Joaquín - Avda.Vicuña Mackenna 4860, Macul, Santiago. E-mail: rhidalgd@uc.cl

\section{Sergio Elórtegui Francioli}

born 1969, studied biology at the Pontificia Universidad Católica de Valparaíso. He is now a PhD candidate in educational sciences at the Pontificia Universidad Católica de Chile. His interests are directed to the field of nature history and education on mediterranean ecosystems and the Pacific islands of Central Chile. Facultad de Ecología y Recursos Naturales, Escuela de Ecoturismo, Universidad Andres Bello, Viña del Mar 7 norte 1348. E-mail: s.elorteguifrancioli@unab.cl 